\title{
Field Performance of Sweet Corn Seed Bio-primed and Coated with Pseudomonas fluorescens AB254
}

\author{
Nancy W. Callan, Don E. Mathre ${ }^{2}$, and James B. Miller ${ }^{1}$ \\ Montana State University, Bozeman, MT 59717 \\ Additional index words. Zea mays, maize, biological control, Pythium ultimum, \\ preemergence damping-off, seed rot, genotypes
}

\begin{abstract}
In field experiments, bio-priming and coating with Pseudomonas fluorescens AB254 consistently protected sweet corn (Zea mays L.) seeds from preemergence damping-off caused by Pythium ultimum Trow. The bio-priming seed treatment was evaluated under various disease pressures and with seeds of three sweet corn genotypes: shrunken-2 supersweet (sh-2), sugary enhancer (se), and sugary (su). While no dampingoff occurred in the $s u$ sweet corn, bio-priming protected sh-2 and se sweet corn seeds at a level equivalent to that obtained by treatment with the fungicide metalaxyl. Biopriming increased seedling height of all three sweet corn genotypes at 4 weeks postplanting. Coating of sweet corn seeds with $P$. fluorescens AB254 provided an equivalent degree of protection from damping-off under all but the most severe conditions.
\end{abstract}

Sweet corn cultivars with increased sweetness are very popular with consumers. However, emergence of cultivars with the shrunken-2 (sh-2) genotype is frequently decreased by pythium preemergence dampingoff when seed is planted into cold soil. Poor seed-ling vigor (Harris and DeMason, 1989) and sensitivity to low imbibition temperature (Basra et al., 1988) also contribute to stand establishment problems in the high-sugar genotype.

Biological and physiological seed treatments are potential alternatives to traditional chemical fungicides for control of pre- and postemergence damping-off. A wide variety of fungal and bacterial strains has been tested as treatments for protection of seeds from preemergence damping-off caused by Pythium spp. Fluorescent pseudomonads have been among the most widely tested biocontrol agents (Callan et al., 1990; Elad and Chet, 1987; Howell and Stipanovic, 1980; Kaiser et al., 1989; Loper, 1988; Osburn et al., 1989; Weller, 1988). Preplant seed hydration or moisturization (Bennett and Waters, 1987), solid matrix priming (Taylor et al., 1988) and osmopriming (Bradford, 1986; Murray, 1990) have also reduced dampingoff by accelerating seedling emergence.

A combination of biological and physiological seed treatments could be expected to increase seedling emergence over that resulting from either treatment used alone. Seed treatment with fungi or bacteria and solid

Received for publication 21 Oct. 1990. Montana Agricultural Experiment Station Publication no. J2565. We thank Kim Phillips for technical assistance. This research was supported in part by the USDA/CSRS Low Input-Sustainable Agriculture Program and the Western Regional IPM Special Grants Program. The donation of seed by Crookham Co., Caldwell, Idaho, is appreciated.

${ }^{1}$ Western Agricultural Research Center, Corvallis, MT 59828.

${ }^{2}$ Dept. of Plant Pathology. matrix priming protected several crops from preemergence damping-off (Harman and Taylor, 1988; Harman et al., 1989). Bacteria present in the osmopriming solution were partially responsible for protection of pea and cucumber (Hadar et al., 1983), table beet (Taylor et al., 1985), and, in some instances, sugar beet seeds from pythium preemergence damping-off (Osburn and Schroth, 1988).

Bio-priming, a combination of biological seed treatment and preplant hydration (Callan et al., 1990), is a strategy for improving the reliability of biological treatments, particularly for crops such as sweet corn that are suceptible to imbibitional chilling injury (Cal and Obendorf, 1972; Herner, 1986). We found that bio-priming sh-2 sweet corn seeds with a strain of Pseudomonas fluorescens isolated from western Montana soil protected them from preemergence damping-off in the greenhouse more consistently than did either preplant hydration or seed bacteria coating alone (Callan et al., 1990 and unpublished data). The research presented here evaluates bio-priming with $P$. fluorescens $A B 254$ for control of pythium preemergence dampingoff of sweet corn in the field. Representatives of three commonly grown sweet corn genotypes, shrunken-2 supersweet (sh-2), sugary enhancer (se), and sugary sweet corn (su) were included.

Seed treatments. All seeds except "nontreated" were surface-disinfested by soaking in $0.25 \% \mathrm{NaOCl}$ for $5 \mathrm{~min}$, after which they were rinsed in tap water for $5 \mathrm{~min}$. For biopriming, 350 of the disinfested seeds were coated with a $1.5 \%$ methylcellulose (MC, medium viscosity; Sigma, St. Louis) suspension of $P$. fluorescens AB254, allowed to dry $2 \mathrm{~h}$, and placed in a single layer in a self-sealing plastic bag lined with two layers of paper towels or germination blotters. Sterile water was added to the blotters in a ratio of $0.5 \mathrm{ml}$ water : $1 \mathrm{~g}$ seed. Seeds were bioprimed for $20 \mathrm{~h}$ at $23 \mathrm{C}$ and planted immediately. Moisture content of bio-primed seed at planting was $35 \%$ to $40 \%$ (fresh weight). Seed treatments included in the various experiments were: 1) bio-primed with $P$. fluorescens $\mathrm{AB} 254 ; 2$ ) coated with $\mathrm{MC}$ only and treated as bio-primed; 3 ) coated with a $\mathrm{MC}$ suspension of $P$. fluorescens AB254 and allowed to dry overnight; 4) coated with MC only and allowed to dry overnight; 5) metalaxyl (Apron 25W, Ciba-Geigy) applied as a slurry at $0.3 \mathrm{~g}$ a.i. $/ \mathrm{kg}$ seed; 6 ) pentachloronitrobenzene (PCNB $75 \mathrm{~W}$ ) applied as a slurry at $2.0 \mathrm{~g}$ a.i./kg seed; and 7) nontreated. In several experiments reported here, seeds treated with MC only (treatment 4) served as the control to isolate bacterial effects. Seven $s h-2$ sweet corn field experiments that included nontreated and MC-treated controls were conducted in 1989 and 1990. Seedling emergence from nontreated seed was slightly but significantly higher than that from MC-treated seed in two experiments, while no difference between these controls was observed in the remaining five (data not presented).

To determine the $P$. fluorescens $A B 254$ colony-forming units on seed (cfu per seed), dilution plating was performed in triplicate at planting as described by Callan et al. (1990). Soil infestation with Pythium ultimum was quantified by the method of AliShtayeh et al. (1986), with the addition of rifampicin $\left(40 \mathrm{mg} \cdot \mathrm{liter}^{-1}\right)$ to the selective medium. Seed moisture at planting was calculated on a fresh-weight basis (Amer. Assn. Cereal Chem., 1979) with three five-seed replications per treatment.

All experiments reported here, except one, were planted by hand, with single-row plots of 50 seeds per plot planted $3.5 \mathrm{~cm}$ deep and $5 \mathrm{~cm}$ apart in a randomized complete-block design with six replications. Soil temperature at $5 \mathrm{~cm}$ was recorded by an automated weather station or with a soil thermograph. Plots were irrigated immediately after planting.

Field experiments were conducted with 'Crisp'n'Sweet 710' (sh-2, 98\% germination, Crookham Co., Caldwell, Idaho) in two locations in Montana: the Western Agricultural Research Center (WARC), Corvallis, and at a commercial farm near Victor. The WARC soil is a Burnt Fork Sandy Loam, pH 7.4, with 5.6 ppm Fe and 530 propagules of $P$. ultimum $/ g$ dry soil. The Victor soil is a Victor Loam, pH 7.4, with 36.2 ppm Fe and 590 propagules of $P$. ultimum/g dry soil. Treatments were as listed in Tables 1 and 2.

A field experiment was conducted at

Table 1. Emergence of $s h-2$ sweet corn in the field. Planted at Victor, Mont.

\begin{tabular}{lcc}
\hline \hline $\begin{array}{l}\text { Seed } \\
\text { treatment }\end{array}$ & $\begin{array}{c}\text { Emergence } \\
(\%)\end{array}$ & $\begin{array}{c}P . \text { fluorescens } \\
\text { AB254 } \\
\text { (cfu/seed) }\end{array}$ \\
\hline AB254 bio-primed & $80.4 \mathrm{a}^{\mathrm{y}}$ & $4.2 \times 10^{8} \mathrm{a}$ \\
Metalaxyl & $78.4 \mathrm{a}$ & $0.0 \mathrm{~b}$ \\
AB254 coated & $72.8 \mathrm{a}$ & $3.5 \times 10^{8} \mathrm{a}$ \\
PCNB & $24.0 \mathrm{~b}$ & $0.0 \mathrm{~b}$ \\
MC only & $17.2 \mathrm{~b}$ & $0.0 \mathrm{~b}$ \\
\hline
\end{tabular}

Planted 16 May 1989.

'Mean separation within columns by NewmanKeuls test, $P=0.05$. 
Table 2. Biological control of preemergence damping-off of sh-2 sweet corn by bio-priming and coating with $P$. fluorescens AB254. Planted at the Western Agricultural Research Center, Corvallis, Mont. $^{\text {zy }}$

\begin{tabular}{|c|c|c|c|c|}
\hline \multirow[b]{2}{*}{$\begin{array}{l}\text { Seed } \\
\text { treatment }\end{array}$} & \multicolumn{2}{|c|}{ Planted 5 May 1989} & \multicolumn{2}{|c|}{ Planted 25 May 1989} \\
\hline & $\begin{array}{c}\text { Emergence } \\
(\%)\end{array}$ & $\begin{array}{c}P . \text { fluorescens } \\
\text { AB254 } \\
\text { (cfu/seed) }\end{array}$ & $\begin{array}{c}\text { Emergence } \\
(\%)\end{array}$ & $\begin{array}{c}\text { P. fluorescens } \\
\text { AB254 } \\
\text { (cfu/seed) }\end{array}$ \\
\hline AB254 bio-primed & $90.3 a^{y}$ & $1.3 \times 10^{8} \mathrm{~b}$ & $89.2 \mathrm{a}$ & $1.7 \times 10^{8} \mathrm{a}$ \\
\hline AB254 coated & $90.0 \mathrm{a}$ & $1.1 \times 10^{9} \mathrm{a}$ & $87.2 \mathrm{ab}$ & $1.2 \times 10^{8} \mathrm{a}$ \\
\hline Metalaxyl & $88.3 \mathrm{a}$ & $0.0 \mathrm{c}$ & $90.4 \mathrm{a}$ & $0.0 \mathrm{~b}$ \\
\hline Hydrated with MC & 83.7 a & $0.0 \mathrm{c}$ & $81.2 \mathrm{~b}$ & $0.0 \mathrm{~b}$ \\
\hline MC only & $76.0 \mathrm{~b}$ & $0.0 \mathrm{c}$ & $56.8 \mathrm{c}$ & $0.0 \mathrm{~b}$ \\
\hline
\end{tabular}

${ }^{7}$ Average soil temperature at $5 \mathrm{~cm}$ was $25.4 / 12.3 \mathrm{C}(\mathrm{max} / \mathrm{min})$ during the 3 days following 5 May and 24.3/10.6C during the 3 days following 25 May.

${ }^{y}$ Mean separation within columns by Newman-Keuls test, $P=0.05$.

Table 3. Seedling emergence and seedling height (4 weeks postplanting) of sweet corn of three genotypes, as affected by bio-priming and coating with Pseudomonas fluorescens AB254. Planted at the Western Agricultural Research Center, Corvallis, Mont. ${ }^{\text {zy }}$

\begin{tabular}{lccccccc}
\hline \hline \multirow{2}{*}{$\begin{array}{l}\text { Seed } \\
\text { treatment }\end{array}$} & \multicolumn{3}{c}{ Emergence (\%) } & & \multicolumn{3}{c}{$\mathrm{Ht}(\mathrm{cm})$} \\
\cline { 2 - 4 } \cline { 7 - 8 } & $s h-2$ & $s e$ & $s u$ & & $s h-2$ & $s e$ & $s u$ \\
\hline \hline AB254 bio-primed & $92.7 \mathrm{a}$ & $95.0 \mathrm{a}$ & $92.0 \mathrm{a}$ & & $40.3 \mathrm{a}$ & $27.7 \mathrm{a}$ & $44.5 \mathrm{a}$ \\
AB254 coated & $93.3 \mathrm{a}$ & $92.3 \mathrm{a}$ & $95.0 \mathrm{a}$ & & $34.1 \mathrm{bc}$ & $24.5 \mathrm{~b}$ & $40.6 \mathrm{~b}$ \\
Hydrated with MC & $85.6 \mathrm{ab}$ & $93.5 \mathrm{a}$ & $94.0 \mathrm{a}$ & & $36.2 \mathrm{~b}$ & $21.8 \mathrm{~b}$ & $39.5 \mathrm{~b}$ \\
Nontreated & $83.3 \mathrm{~b}$ & $81.3 \mathrm{~b}$ & $92.7 \mathrm{a}$ & $30.3 \mathrm{c}$ & $15.7 \mathrm{c}$ & $33.8 \mathrm{c}$ \\
\hline
\end{tabular}

${ }^{2}$ Planted 18 July 1989. Average soil temperature at $5 \mathrm{~cm}$ was $33.0 / 18.3 \mathrm{C}$ ( $\left.\mathrm{max} / \mathrm{min}\right)$ during the 3 days following planting.

'There was a significant treatment $\times$ genotype interaction for emergence $(P=0.05)$. Mean separation within columns by Newman-Keuls test, $P=0.05$. $\mathrm{LSD}_{0.05}$ for comparing genotype means within a treatment is $6.4 \%$ for emergence and $1.4 \mathrm{~cm}$ for plant height.

Table 4. Biological control of preemergence damping-off in two sh-2 sweet corn cultivars by bio-priming and coating with Pseudomonas fluorescens AB254. Planted at the Western Agricultural Research Center, Corvallis, Mont.

\begin{tabular}{lcc}
\hline \hline & \multicolumn{2}{c}{ Emergence (\%) } \\
\cline { 2 - 3 } Seed & Crisp'n'Sweet & How Sweet \\
treatment & 620 & It Is \\
\hline AB254 bio-primedx & $64.7 \mathrm{a}$ & $50.4 \mathrm{a}$ \\
AB254 coated & $51.0 \mathrm{a}$ & $37.8 \mathrm{~b}$ \\
Metalaxyl & $57.8 \mathrm{a}$ & $44.4 \mathrm{ab}$ \\
Nontreated & $9.7 \mathrm{a}$ & $3.2 \mathrm{c}$ \\
\hline
\end{tabular}

Planted 12 May 1989. Average soil temperature at $5 \mathrm{~cm}$ was $21.9 / 9.7 \mathrm{C}(\mathrm{max} / \mathrm{min})$ during the 3 days following planting.

Mean separation within columns by NewmanKeuls test, $P=0.05$. LSD $_{0.05}$ for comparing cultivar means within a treatment is $9.6 \%$.

${ }^{x}$ 'Crisp'n'Sweet 620 ' had $4.8 \times 10^{8} \mathrm{cfu} P$. fluorescens AB254/seed and 'How Sweet It Is' had $3.2 \times 10^{8} \mathrm{cfu} / \mathrm{seed}$

'Crisp'n' Sweet 620' had $4.5 \times 10^{8} \mathrm{cfu} P$. fluorescens $\mathrm{AB} 254 /$ seed and 'How Sweet It Is' had $3.0 \times 10^{8} \mathrm{cfu} / \mathrm{seed}$.

WARC to evaluate the effectiveness of the bio-priming seed treatment for protection of seeds of three sweet corn endosperm genotypes from damping-off. Seeds of sh-2 ('Crisp'n'Sweet 710'), se ('Miracle', 99\% germination), and su sweet corn ('Earlivee', 99\% germination) were planted by hand. Treatments were as listed in Table 3. Bioprimed and coated treatments had 1.5 to 3.3 $\times 10^{8} \mathrm{cfu}$ of $P$. fluorescens AB254/seed at planting. There was no difference in cfu per seed among bacterial treatments. The height to the tip of the longest leaf of 12 seedlings per plot was recorded 4 weeks after planting.

An experiment involving two sh-2 culti- vars, 'Crisp'n'Sweet 620' (germination 95\%) and 'How Sweet It Is' (germination 97\%, Crookham Co.), was planted at WARC using a cone plot seeder. Plots were $6 \mathrm{~m}$ long, with four replications of 80 seeds per plot in a split-plot design. Treatments were as listed in Table 4. Bacterial treatments did not differ in cfu of $P$. fluorescens AB254 per seed.

Disease pressure. Conditions of severe (Table 1), moderate (Table 2, 25 May planting), and low disease pressure (Table 2, 5 May planting) were encountered, as indicated by the level of damping-off in the MConly treatment. Disease pressure was higher and minimum postplant temperatures were lower in May at WARC (9 to 11C) than in July (18C). Even with the severe disease pressure at Victor (Table 1), both bio-priming and coating with $P$. fluorescens AB254 provided protection equal to or greater than the fungicide metalaxyl. Damping-off at Victor was primarily due to attack by Pythium spp., as shown by the ineffectiveness of PCNB, a fungicide effective against Rhizoctonia solani Kuhn but with no activity against Pythium spp., and the excellent control provided by metalaxyl. Pythium ultimum previously was determined to be responsible for damping-off at WARC (data not presented).

Under moderate disease pressure at WARC (Table 2, 25 May), both biological treatments protected seeds from damping-off at a level equivalent to that provided by metalaxyl. Hydration of seed also provided significant protection but less than did metalaxyl. Finally, under low disease pressure, all seed treatments, including hydration with $\mathrm{MC}$, increased emergence over that of seeds treated with MC alone (Table 2, 5 May).

Sweet corn genotype. High soil tempera- tures at planting contributed to relatively low disease pressure in this field experiment, as demonstrated by strong seedling emergence in the nontreated controls (Table 3). The three sweet corn genotypes tested differed in the amount of preemergence damping-off observed. Seedling emergence of the $s u$ sweet corn ('Earlivee') was high with all treatments, but damping-off occurred in the nontreated sh-2 ('Crisp'n'Sweet 710') and se ('Miracle') genotypes. In these cultivars, both bio-priming and coating with $P$. fluorescens AB254 provided significant seed protection. Metalaxyl also protected seeds of the $s h-2$ cultivar (91.7\% emergence), indicating the involvement of $P$. ultimum. Preplant hydration conferred a greater degree of protection to the se genotype than to the $s h-2$ sweet corn. Bennett and Waters (1987) and others have observed that $s u$ sweet corn seedling emergence was normally higher than that of $s h-2$ or se sweet corn. Seedling vigor of $s u$ sweet corn is greater than that of the $s h-2$ genotype, and exudation on imbibition is less (Wann, 1986), presumably resulting in a lower level of stimulation of spore germination and seed infection by $P$. ultimum. Moisture uptake by $s u$ seed during bio-priming (27\%) was less than that of $s h-2$ or se seed $(36 \%$ and $34 \%$, respectively). Reduced imbibition of $s u$ sweet corn seed was also noted by Styer and Cantliffe (1983).

Early seedling growth was increased by bio-priming. At 4 weeks postplanting, seedlings of all genotypes were tallest from bioprimed seed, even though no damping-off was apparent in the $s u$ sweet corn. This result was observed to a lesser extent with preplant hydration (Table 3). Coating with $P$. fluorescens AB254 increased seedling height over the nontreated control in the se and $s u$ sweet corn. Similarly, El-Meleigi (1989) found sweet corn seedling growth to be increased by seed treatment with several Pseudomonas spp. isolates. Increased early seedling growth resulting from bio-priming seed with $P$. fluorescens AB254 may have resulted from the combined effects of accelerated germination due to preplant seed hydration, alleviation of imbibitional chilling injury, and reduction of the effects of $P$. $u l$ timum on the seed and seedling root system through colonization by $P$. fluorescens $\mathrm{AB} 254$, a member of a group of bacteria known to include plant growth-promoting rhizobacteria (Elad et al., 1987).

Sh-2 sweet corn cultivars. Preemergence damping-off of both $s h-2$ cultivars was reduced considerably by bio-priming with $P$. fluorescens AB254. Seed coating with $P$. fluorescens AB254 provided protection similar to bio-priming with the more vigorous 'Crisp'n'Sweet 620', but was slightly less effective with the weaker 'How Sweet It Is' (Table 4). Treatment with metalaxyl provided protection similar to the biological treatments. There was no significant interaction between cultivar and treatment.

Bio-priming sweet corn seeds with $P$. fluorescens AB254 provided consistent biological control of pythium preemergence damping-off in this series of field experi- 
ments conducted during the 1989 growing season. In several of the experiments with low disease pressure, seed hydration without the addition of a biocontrol agent was sufficient to increase emergence to the level obtained with bio-priming or treatment with metalaxyl. However, combining these two strategies, i.e., bio-priming, resulted in the most reliable seed protection under all conditions.

\section{Literature Cited}

Ali-Shtayeh, M.S., C.L. Lim-Ho, and M.W. Dick. 1986. An improved method and medium for quantitative estimates of populations of Pythium species from soil. Trans. Br. Mycol. Soc. 86:3947.

American Association of Cereal Chemists. 1979. Cereal laboratory methods. Amer. Assn. Cereal Chem. (AACC), St. Paul.

Basra, AS., S. Bedi, and C.P. Malik. 1988. Accelerated germination of maize seeds under chilling stress by osmotic priming and associated changes in embryo phospholipids. Ann. Bot. 61:635-639.

Bennett, M.A. and L. Waters, Jr. 1987. Germination and emergence of high-sugar sweet corn is improved by presowing hydration of seed. HortScience 22:236-238.

Bradford, K.J. 1986. Manipulation of seed water relations via osmotic priming to improve germination under stress conditions. HortScience 21:1105-1112.

Cal, J.P. and R.L. Obendorf. 1972. Imbibitional chilling injury in Zea mays L. altered by initial kernel moisture and maternal parent. Crop Sci. 12:369-373.

Callan, N.W., D.E. Mathre, and J.B. Miller. 1990. Bio-priming seed treatment for control of Pythium ultimum preemergence damping-off in sh2 sweet corn. Plant Dis. 74:368-372.

Elad, Y. and I. Chet. 1987. Possible role of competition for nutrients in biocontrol of Pythium damping-off by bacteria. Phytopathology 77:190-195.

Elad, Y., I. Chet, and R. Baker. 1987. Increased growth response of plants induced by rhizobacteria antagonistic to soilborne pathogenic fungi. Plant Soil 98:325-330.

El-Meleigi, M.A. 1989. Effect of soil Pseudomonas isolates applied to corn, sorghum and wheat seeds on seedling growth and corn yield. Can. J. Plant Sci. 69:101-108.

Hadar, Y., G.E. Harman, A.G. Taylor, and J.M. Norton. 1983. Effects of pregermination of pea and cucumber seeds and of seed treatment with Enterobacter cloacae on rots caused by Pythium. Phytopathology 73:1322-1325.

Harman, G.E. and A.G. Taylor. 1988. Improved seedling emergence by integration of biological control agents at favorable $\mathrm{pH}$ levels with solid matrix priming. Phytopathology 78:520-525.

Harman, G.E., A.G. Taylor, and T.E. Stasz. 1989. Combining effective strains of Trichoderma harzianum and solid matrix priming to improve biological seed treatments. Plant Dis. 73:631637.

Harris, M.J. and D.A. DeMason. 1989. Comparative kernel structure of three endosperm mutants relating to seed viability and seedling vigor. Bot. Gaz. 150:50-62.

Herner, R.C. 1986. Germination under cold soil conditions. HortScience 21:1118-1122.

Howell, C.R. and R.D. Stipanovic. 1980. Suppression of Pythium ultimum induced dampingoff of cotton seedlings by Pseudomonas fluorescens and its antibiotic; pyoluteorin. Phytopathology 70:712-715.
Kaiser, W.J., R.M. Hannan, and D.M. Weller 1989. Biological control of seed rot and preemergence damping-off of chickpea with fluorescent pseudomonads. Soil Biol. Biochem. 21:269-273

Loper, J.E. 1988. Role of fluorescent siderophore production in biological control of Pythium ultimum by a Pseudomonas fluorescens strain. Phytopathology 78:166-172.

Murray, G.A. 1990. Priming sweet corn seed to improve emergence under cool conditions. HortScience 25:231.

Osburn, R.M. and M.N. Schroth. 1988. Effect of osmopriming sugar beet seed on exudation and subsequent damping-off caused by Pythium ultimum. Phytopathology 78:1246-1250.

Osburn, R.M., M.N. Schroth, J.G. Hancock, and M. Hendson. 1989. Dynamics of sugar beet seed colonization by Pythium ultimum and Pseudomonas species: effects on seed rot and damping- off. Phytopathology 79:709-716.

Styer, R.C. and D.J. Cantliffe. 1983. Changes in seed structure and composition during development and their effects on leakage in two endosperm mutants of sweet corn. J. Amer. Soc. Hort. Sci. 108:721-728.

Taylor, A.G., Y. Hadar, J.M. Norton, and G.E. Harman. 1985. Influence of presowing seed treatments of table beets on the susceptibility to damping-off caused by Pythium. J. Amer. Soc. Hort. Sci. 110:516-519.

Taylor, A.G., D.E. Klein, and T.H. Whitlow. 1988. SMP: Solid matrix priming of seeds. Scientia Hort. 37:1-11.

Wann, E.V. 1986. Leaching of metabolites during imbibition of sweet corn seed of different endosperm genotypes. Crop Sci. 26:731-733.

Weller, ED.M. 1988. Biological control of soilborne plant pathogens in the rhizosphere with bacteria. Annu. Rev. Phytopathol. 26:379-407. 